\title{
MODEL PEMBELAJARAN PORTOFOLIO DALAM PEMBELAJARARAN TEMATIK TERPADU
}

\author{
Ulfah Elkhaira ${ }^{1,}$ Reinita $^{2}$ \\ Universitas Negeri Padang ${ }^{1,2}$ \\ elkhairanoor@gmail.com ${ }^{1}$
}

\begin{abstract}
ABSTRAK
Penelitian ini bertujuan untuk mendeskripsikan peningkatan hasil belajar dengan menggunakan model Portofolio pada pembelajaran tematik terpadu. Pada pelaksanannya guru belum menggunakan model pembelajaran yang dapat membangkitkan semangat siswa, dan kurang memberikan permasalahan pada pembelajaran dan hasil pekerjaan siswa tidak di simpan menjadi satu sehingga sulit untuk melihat perkembangan siswa. Jenis penelitian ini adalah Penelitian Tindakan Kelas dan menggunakan pendekatan kualitatif dan kuantitatif. Subjek penelitian ini adalah siswa kelas V SD Data penelitian ini berupa hasil pengamatan dan tes dari setiap tindakan perbaikan pembelajaran dengan menerapkan model Portofolio.Model portofolio ini memiliki 6 tahap yaitu "1) mengidentifikasi masalah, 2) memilih masalah untuk kajian kelas, 3) mengumpulkan informasi tentang masalah yang dikaji di kelas. 4) mengembangkan portofolio di kelas, 5) kumpulan bahan, 6) seksi penayangan portofolio. Hasil penelitian ini menunjukkan pada siklus I rata-rata nilai kognitif siswa persentasenya adalah 71,5 dan pada siklus kedua mengalami peningkatan bahwa ratarata nilai kognitif siswa menjadi 92. Simpulan, bahwa terdapat peningkatan hasil belajar siswa yang signifikan setelah diteapkan model portofolio pada pembelajaran tematik terpadu di kelas V SD.
\end{abstract}

Kata Kunci: Model Portofolio, Hasil Belajar

\section{ABSTRACT}

This study aims to describe the improvement of learning outcomes by using the Portfolio model in integrated thematic learning of fifth grade. In the implementation the teacher has not used a learning model that can arouse students' enthusiasm, and does not provide problems in learning and student work outcomes are not kept together so it is difficult to see student development. This type of research is Classroom Action Research and uses qualitative and quantitative approaches. The subject of this research is the fifth grade elementary school students. The data of this study are the results of observations and tests of each learning improvement action by applying the portfolio model. This portfolio model has 6 stages namely "1) identifying the problem, 2) selecting the problem for the class study, 3) collecting information about the problems studied in class. 4) developing portfolios in class, 5) collection of materials, 6) portfolio display section. The results of this study indicate that in the first cycle the average cognitive value of students was 71.5 and in the second cycle increased that the average cognitive value of students became 92. Conclusion, that there was a significant increase in student learning outcomes after applying the portfolio model to learning integrated thematic in grade V elementary school.

Keywords: Portfolio Model, Learning Outcomes 


\section{PENDAHULUAN}

Perencanaan dan pengaturan kompetensi belajar siswa dan hasil belajar yang harus dicapai oleh siswa, tidak hanya itu kurikulum juga sebagai perencanaan penilaian, kegiatan belajar mengajar serta pemberdayaan sumber daya pendidikan dalam pengembangan kurikulum sekolah. Dalam kurikulum 2013 kompetensi yang dikembangkan tidak hanya pengetahuan saja tetapi juga kompetensi sikap dan keterampilan. Hal ini senada dengan pernyataan Reinita (2017) yaitu "Pembelajaran di sekolah dasartidak hanya berpusat pada ranah pengetahuan saja, tetapi juga ranah sikap dan keterampilan"

Pembelajaran tematik terpadu kurikulum 2013, pengetahuan yang di dapat oleh siswa tidak hanya semata-mata dari guru, tetapi siswa juga harus secara aktif mengembangkan ilmu pengetahuan yang dimilikinya terhadap masalah atau materi yang dikaji secara mendalam dengan melihat beberapa sumber atau referensi secara luas dan guru juga harus bersifat fleksibel yaitu mau menerima pendapat dari pemikiran siswa dan mengembangkannya bersama-sama secara luas, sehingga proses pembelajaran tidak monoton berpusat pada guru saja.

Namun, kegiatan pembelajaran yang dilaksanakan tidak sesuai dengan yang diharapkan. siswa kurang memahami materi pembelajaran secara mendalam, siswa tidak menggunakan berbagai sumber bacaan atau referensi secara luas, pekerjaan siswa tidak disimpan menjadi satu sehingga sulit untuk melihat perkembangan belajar siswa. Dari permasalahan di atas merujuk pada hasil belajar siswa, pada proses pembelajaran timbul permasalahan dari segi siswa, maka guru lebih kreatif dan inovatif dalam menghasilkan proses pembelajaran yang menarik sehingga siswa mampu berfikir kritis dalam proses pembelajaran

Adapun salah satu tindakan yang dapat dilakukan oleh guru adalah dengan menggunakan model pembelajaran yang tepat dalam mengimplementasikan pembelajaran tematik terpadu, salah satu model pembelajaran yang dapat digunakan untuk mengimplementasikan pembelajaran tematik terpadu di Sekolah Dasar menurut penulis adalah model Portofolio.

Model Portofolio cocok diimplementasikan pada pembelajaran tematik terpadu karena siswa akan diarahkan untuk berpikir kritis dan memahami materi secara mendalam, siswa langsung menggali informasi mengenai masalah yang akan di kajinya dalam kehidupan nyata, melalui beberapa referensi seperti sumber bacaan, berita, surat kabar ataupun tanya jawab, Siswa aktif bekerja sama di dalam kelompok, setiap siswa bebas mengemukakan idenya dengan teman yang lain dan mengaitkan pengalaman kehidupan nyata siswa dengan materi tersebut.

Sejalan dengan hal tersebut, menurut Taniredja, dkk (2015) menyatakan bahwa : "Model pembelajaran portofoliomerupakan suatu inovasi yang dirancang untuk membantu peserta didik memahami materi pembelajaran secara mendalam dan luas melalui pengembangan materi yang telah dikaji di kelas dengan menggunakan berbagai sumber bacaan dan referensi" 


\section{METODE PENELITIAN}

Penelitian dilaksanakan di SD Negeri 01 Campago Ipuh Kota Bukittinggi. Subjek Penelitian Tindakan Kelas ini adalah siswa kelas V SD Negeri 01 Campago Ipuh Kota Bukittinggi yakni dengan jumlah siswa yang terdaftar pada tahun pelajaran 2018/2019 adalah 26 orang yang terdiri dari 11 orang siswa laki-laki dan 15 orang siswa perempuan, guru kelas sebagai observer, dan peneliti sebagai guru praktisi.

Penelitian ini dilakukan untuk meningkatkan kemampuan berpikir kritis menggunakan model Portofolio pada pembelajaran tematik terpadu di sekolah dasar. Penelitian ini menggunakan penelitian kualitatif dan kuantitatif. Jenis penelitian ini adalah "classroom action research" (penelitian tindakan kelas).

Penelitian tindakan kelas yang dilaksanakan menggunakan model siklus yang dikembangkan oleh Kemmis dan Taggart (dalam Wiriaatmadja, 2012), yang mempunyai 4 tahap yaitu perencanaan, tindakan, pengamatan, dan refleksi. Penelitian ini dilaksanakan dalam 3 siklus yaitu siklus I, 2 dan siklus 3.

Sumber data penelitian adalah proses pembelajaran menulis laporan percobaan, kegiatan penilaian, perilaku guru dan siswa sewaktu proses pembelajaran. Data diperoleh dari subjek yang diteliti yakni peneliti, guru kelas (observer), dan siswa kelas V SDN 01 Campago Ipuh Kota Bukittinggi. Data penelitian ini dikumpulkan dengan menggunakan lembar observasi dan lembaran tes.

Agar tujuan penelitian ini tercapai digunakan instrumen penelitian yaitu berupa lembaran observasi, lembar tes dan lembar non tes. Aspek yang diamati melalui pedoman observasi adalah yang berkaitan dengan RPP, pelaksanaan pembelajaran pada aspek guru dan aspek peserta didik. Lembar tes digunakan untuk memperkuat data observasi yang terjadi dalam kelas terutama pada butir penguasaan materi pembelajaran oleh peserta didik. Data yang diperoleh dalam penelitian dianalisis dengan menggunakan analisis kualitatif dan kuantitatif. Model analisis data kualitatif yang dijelaskan oleh Miles dan Huberman (dalam Wiriatmadja 2007) yakni "Analisis data dimulai dengan menelaah sejak mulai pengumpulan data sampai seluruh data terkumpul, data tersebut direduksi berdasarkan masalah yang diteliti, diikuti penyajian data dan terakhir penyimpulan atau verifikasi”. Tahap analisis yang demikian dilakukan berulang-ulang begitu data selesai dikumpulkan pada setiap tahap pengumpulan data dalam setiap tindakan. Sedangkan model analisis data kuantitatif yaitu terhadap penilaian proses belajar siswa dalam Kunandar (2015), dengan menggunakan rumus perhitungan dan penskoran untuk pengetahuan dan keterampilan, yaitu:

Nilai $=$ Jumlah skor yang diperoleh siswa x 100

Jumlah skor maksimal

Konversi dengan skala 4:

Nilai akhir siswa $=\frac{\text { Nilai } \mathrm{x}}{100}$

Sedangkan untuk menghitung persentase hasil pengamatan praktik pembelajaran, dalam Kemendikbud (2014), dengan rumus sebagai berikut: 
Nilai $=\frac{\text { Jumlah skor yang diperoleh }}{\text { Jumlah skor maksimal }} \times 100 \%$

Tabel 1

Kriteria Taraf Keberhasilan

\begin{tabular}{cc}
\hline Peringkat & Nilai \\
\hline Amat Baik $(\mathrm{AB})$ & $90<\mathrm{A} \leq 100$ \\
\hline Baik $(\mathrm{B})$ & $75<\mathrm{B} \leq 90$ \\
\hline Cukup $(\mathrm{C})$ & $60<\mathrm{C} \leq 75$ \\
\hline Kurang $(\mathrm{K})$ & $\leq 60$ \\
\hline
\end{tabular}

\section{HASIL PENELITIAN}

\section{Siklus 1}

Perencanaan ditahap awal dilakukan dalam penelitian ini pada proses pembelajaran tematik terpadu ini menggunakan model Portofolio. Sebelum pelaksanaan terlebih dahulu disusun rancangan pembelajaran (RPP), yang mana RPP ini disusun secara kolaboratif antara peneliti dengan guru kelas V SDN 01 Campago Ipuh.

Pelaksanaan pembelajaran tematik terpadu menggunakan model Portofolio di kelas V SDN 01 Campago Ipuh pada siklus 1 dilaksankan pada hari Senin 05 November 2018 dan Rabu 07 November 2018 pada jam 07.30 - 12.30 WIB. Pada langkah mengidentifikasi masalah, guru membangiktkan pengetahuan siswa berdasarkan teks bacaan yang berjudul gotong royong. Pada langkah memilih masalah untuk kajian kelas, guru membagi siswa menjadi 5-6 kelompok dan di dalam kelompok siswa berdiskusi mengenai masalah apa saja yang akan terjadi apabila tidak adanya gotong royong di masyarakat. Pada langkah mengumpulkan informasi mengenai masalah yang akan diambil, siswa secara individu dan kelompok mencari dan mencatat informasi di perpustakaan terkait permasalahanpermasalahan yang terjadi apabila tidak adananya gotong royong dilingkungan masyarakat. Setelah itu siswa berdiskusi mengisi LKPD yang telah diperoleh. Pada langkah mengembangkan portofolio kelas, Guru menginstruksikan kepada siswa untuk mengembangkan informasi yang telah ia temukan tadi dan siswa mendengarkan instruksi guru mengenai rincian portofolio yang akan dikerjakan siswa mulai dari menuliskan masalahmasalah apa saja yang terjadi apabila tidak ada gotong royong, memilih satu masalah yang yang akan dikaji siswa, menuliskan sebab dan akibat mengenai masalah tersebut dan menuliskan solusi terhadap masalah yang telah dipilih siswa.

Pada langkah kumpulan bahan Siswa saling bekerjasama mengumpulkan bahan-bahan yang telah mereka kerjakan kedalam 1 map jepit perkelompok. Pada langkah menyajikan portofolio kelas Masing-masing kelompok menampilkan hasil diskusi ke depan kelas dan kelompok lain memperhatikan penampilan dari temannya.

Pengamatan RPP Berdasarkan pengamatan observer, susunan komponen RPP yang peneliti buat diperbaiki dan disesuaikan dengan Peraturan Menteri Pendidikan dan Kebudayaan Republik Indonesia No. 103 dan 104 Tahun 2014. Hasil pengamatan yang dilakukan oleh observer terhadap format RPP diperoleh persentase penilaian $71 \%$ dengan 
taraf keberhasilan cukup. Pengamatan juga dilakukan pada pelaksanaan pembelajaran dimana persentase keberhasilan guru dalam melaksanakan kegiatan pembelajaran di siklus I adalah 78, dengan kriteria keberhasilan baik. Sedangkan, berdasarkan hasil pengamatan penilaian proses kegiatan siswa menggunakan model Portofolio adalah 79\%, dengan kriteria keberhasilan baik. Hasil belajar dalam penilaian sikap yang diperoleh siswa dengan persentase nilai rata-rata 72 dan taraf keberhasilan cukup. Penilaian pengetahuan yang diperoleh siswa dengan persentase nilai 71,5 dan taraf keberhasilan baik.Penilaian keterampilan dilakukan dengan persentase nilai 65,5 dan taraf keberhasilan kurang.

Refleksi yang dilakukan pada siklus I, disimpulkan bahwa guru belum mengarahkan siswanya untuk duduk dalam kelompoknya masing-masing. guru belum mengarahkan siswa masing-masing dalam kelompoknya untuk mengembangkan masalah yang telah diambilnya serta guru dan siswa belum mengkaji masalah tersebut dalam kelompoknya. guru belum mengarahkan siswa untuk mengumpulkan bahannya perkelompok dalam satu map jepit dan hanya mengumpulkan perkelompok dan guru sendiri memasukkan dalam map jepit, sehingga belum terlihat kerjasama anatara siswa dalam menyusun hasil kerja masing-masing kelompoknya.

Aspek siswa, siswa belum diarahkan untuk duduk di kelompoknya masing-masing sehinggaiswa menjadi meribut, siswa belum mengembangkan masalah yang akan dikajinya dalam kelompoknya masing-masing, siswa belum mendengarkan guru saat mengaitkan materi dengan pengetahuan lain yang relevan, perkembangan IPTEK, dan kehidupan nyata, siswa belum melaksanakan pembelajaran yang bersifat kontekstual, siswa belum bekerjasama menyusun hasil kerjanya dalam satu map jepit. Berdasarkan hasil kolaborasi dan analisa observer dan peneliti masih banyak deskriptor yang belum tampak ataupun yang masih belum terlaksana. Dengan demikian, kekurangan-kekurangan yang ditemui pada siklus I akan diperbaiki pada siklus II.

\section{Siklus 2}

Perencanaan tindakan pada siklus II dilakukan sebagai upaya untuk mengatasi permasalahan dalam pembelajaran yang ditemukan pada siklus I. Pada tahap pelaksanaan pembelajaran tematik terpadu menggunakan model Portofolio di kelas V SDN 01 Campago Ipuh pada siklus 1 dilaksankan pada hari Sabtu 10 november pada jam 07.30 - 12.30 WIB. Berdasarkan RPP yang disusun, pembelajaran tematik terpadu menggunakan model Portofolio. Pada langkah mengidentifikasi masalah guru memajang gambar banjir dan siswa bertanya jawab mengenai masalah yang akan diambil. Pada langkah memilih masalah untuk kajian kelas, siswa mendiskusikan dalam kelompoknya masing-masing masalah apa saja yag terjadi apabila tidak ada tanggung jawab di masyarakat. Pada langkah mengumpulkan informasi mengenai masalah yang akan diambil, siswa secara individu dan kelompok mencari dan mencatat informasi di perpustakaan terkait permasalahan-permasalahan yang terjadi apabila tidak adananya gotong royong dilingkungan masyarakat. Setelah itu siswa berdiskusi mengisi LKPD yang telah diperoleh. Pada langkah mengembangkan portofolio kelas, Guru menginstruksikan kepada siswa untuk mengembangkan informasi yang telah ia temukan tadi dan siswa mendengarkan instruksi guru mengenai rincian portofolio yang akan dikerjakan siswa mulai dari menuliskan masalah- masalah apa saja yang terjadi apabila tidak ada gotong royong, memilih satu masalah yang yang akan dikaji siswa, menuliskan sebab dan akibat 
mengenai masalah tersebut dan menuliskan solusi terhadap masalah yang telah dipilih siswa. Pada langkah kumpulan bahan Siswa saling bekerjasama mengumpulkan bahan-bahan yang telah mereka kerjakan kedalam 1 map jepit perkelompok. Pada langkah menyajikan portofolio kelas Masing-masing kelompok menampilkan hasil diskusi ke depan kelas dan kelompok lain memperhatikan penampilan dari temannya.Pengamatan RPP dilakukan dalam kegiatan pembelajaran siklus II sudah baik dan diperoleh persentase penilaian 92\%. Pada pelaksanaan pembelajaran terlihat aktivitas guru dalam kegiatan pembelajaran di siklus ini sudah mengalami peningkatan dibanding siklus I. Hasil pengamatan yang dilakukan oleh observer terhadap aktivitas guru dalam kegiatan pembelajaran siklus 2, diperoleh persentase penilaian $94 \%$ dengan taraf keberhasilan baik.

Aktivitas siswa dalam kegiatan pembelajaran siklus II ini sudah baik, dan terlaksana sesuai dengan rencana yang telah disusun.hasil pengamatan yang dilakukan oleh observer terhadap aktivitas siswa dalam kegiatan pembelajaran siklus II, diperoleh persentase penilaian $94 \%$ dengan taraf keberhasilan baik. Hasil belajar dalam penilaian sikap yang diperoleh siswa dengan nilai 86 dan taraf keberhasilan baik .Penilaian pengetahuan yang diperoleh siswa dengan persentase nilai 91 dan taraf keberhasilan sangat baik. Penilaian keterampilan dilakukan saat melakukan diskusi kelompok dengan persentase nilai 85 dan taraf keberhasilan baik.

Dari refleksi pada siklus I, disimpulkan bahwa guru belum mengarahkan siswanya untuk duduk dalam kelompoknya masing-masing. guru belum mengarahkan siswa masingmasing dalam kelompoknya untuk mengembangkan masalah yang telah diambilnya serta guru dan siswa belum mengkaji masalah tersebut dalam kelompoknya. guru belum mengarahkan siswa untuk mengumpulkan bahannya perkelompok dalam satu map jepit dan hanya mengumpulkan perkelompok dan guru sendiri memasukkan dalam map jepit, sehingga belum terlihat kerjasama anatara siswa dalam menyusun hasil kerja masing-masing kelompoknya.

Aspek siswa, siswa belum diarahkan untuk duduk di kelompoknya masing-masing sehinggaiswa menjadi meribut, siswa belum mengembangkan masalah yang akan dikajinya dalam kelompoknya masing-masing, siswa belum mendengarkan guru saat mengaitkan materi dengan pengetahuan lain yang relevan, perkembangan IPTEK, dan kehidupan nyata, siswa belum melaksanakan pembelajaran yang bersifat kontekstual, siswa belum bekerjasama menyusun hasil kerjanya dalam satu map jepit.

Berdasarkan hasil kolaborasi dan analisa observer dan peneliti pada siklus II, baik dari aspek guru dan aspek siswa semua deskriptor sudah terlaksana dengan baik walau masih ada deskriptor-deskriptor yang belum terlaksana. Namun secara keseluruhan aspek guru dan aspek siswa sudah terlaksana dengan baik sesuai langkah-langkah model Portofolio. Dengan begitu penelitian berakhir di siklus II. Dalam penelitian sebelumnya yang dilakukan oleh Lestari (2016) Jumlah siswa yang memenuhi ketuntasan klasikal siswa pada siklus II setelah diterapkan model pembelajaran menggunakan model portofolio yaitu 40 siswa atau 93,02\%. Siswa yang belum memenuhi ketuntasan klasikal sebanyak 3 siswa atau 6,97\%. Siswa tersebut dibimbing dan diarahkan agar memenuhi ketuntasan klasikal yang ditetapkan. Dengan demikian dapat disimpulkan bahwa pembealajaran tematik menggunakan model portofolio dapat meningkatkan hasil belajar siswa. 


\section{PEMBAHASAN}

Hasil penelitian pada proses perencanaan bahwa pelaksanaan pembelajaran dalam meningkatkan kemampuan berpikir kritis menggunakan model Portofolio dalam pembelajaran tematik di Sekolah Dasar, terungkap bahwa guru membuat perencanaan yang dimulai dengan membuat rancangan pembelajaran dalam bentuk Rencana Pelaksanaan Pembelajaran (RPP) sesuai dengan komponen RPP. Menurut Permendikbud No. 103 Tahun 2014 tentang Pembelajaran pada Pendidikan Dasar dan Pendidikan Menengah, RPP mencakup: "(1) identitas sekolah/madrasah, mata pelajaran, dan kelas/semester; (2) alokasi waktu; (3) KI, KD, indikator pencapaian kompetensi; (4) materi pembelajaran; (5) kegiatan pembelajaran; (6) penilaian; dan (7) media/alat, bahan, dan sumber belajar".

Penyusunan perencanaan siklus I ditemukan beberapa kendala, seperti perencanaan media pembelajaran tidak sesuai dengan karakteristik siswa dan lain-lain. Kendala yang ditemui pada siklus I ini menjadi perhatian dan dicari solusinya, sehingga perencanaan pembelajaran pada siklus II mencapai keberhasilan dengan sangat baik sehingga dapat meningkatkan kemampuan berpikir siswa.

Pelaksanaan pembelajaran dengan mengikuti langkah-langkah dalam model Portofolio pada siklus I sudah masuk dalam kriteria cukup, namun masih belum sepenuhnya terlaksana secara maksimal. Pada kegiatan awal dalam mengkondisikan kelas untuk belajar, terdapat deskriptor yang sudah terlaksana yaitu guru sudah mengkondisikan kelas agar bersih dan rapi, guru sudah mengecek kehadiran siswa dan membimbing siswa untuk berdoa dan guru menyampaikan tujuan pembelajaran.

Pada langkah memilih masalah untuk dijadikan kajian kelas guru belum membimbing siswa duduk dalam kelompoknya masing-masing. Pada langkah mengumpulkan informasi mengenai masalah yang di ambil guru sudah mengarahkan siswa untuk ke perpustakaan sekolah mencari informasi, masing-masing kelompok sudah mengumpulkan informasi yang berhubungan dengan pemecahan masalah yang telah dipilihnya tadi, Pada langkah mengembangkan portofolio kelas siswa dalam masing-masing kelompok sudah mengembangkan masalah yang telah dipilihnya tadi dalam bentuk portofolio kelas dan guru sudah mengarahkan siswa mencari pemecahan masalah dengan bersumber dari buku yang telah dibacanya tadi

Pada langkah kumpulan bahan siswa sudah mendengarkan penjelasan guru mengenai spesifikasi portofolio yakni terdapat bagian penyajian dan bagian dokumentasi pada setiap kelompok guru sudah mengarahkan siswa mengumpulkan bahan portofolio

Dari hasil pengamatan pelaksanaan penelitian keberhasilan aktivitas guru pada siklus I dapat dilihat hasil penilaian kegiatan guru adalah $78 \%$ (B) Sedangkan hasil penilaian kegiatan siswa pada siklus adalah $79 \%$ dengan kriteria baik (B).

Hasil belajar merupakan suatu prestasi belajar siswa, sebagai indikator tolak ukur penentuan perubahan prilaku siswa. Mulyasa mengemukakan (2010:212) "Hasil belajar merupakan prestasi belajar siswa secara keseluruhan yang menjadi indikator kompetensi dasar dan derajat perubahan perilaku yang bersangkutan”.

Hasil penelitian siklus I pada RPP rata-rata 71\% (Cukup), meningkat pada siklus II menjadi 92\% (Sangat baik). Pelaksanaan siklus I pada aspek guru rata-rata $78 \%$ (baik), meningkat pada siklus II menjadi 94\% (sangat baik). Pelaksanaan siklus I pada aspek siswa rata-rata $79 \%$ (cukup), meningkat pada siklus II menjadi 94\% (sangat baik). Hasil belajar 
siswa pada siklus I rata-rata 72,5 (Cukup), meningkat pada siklus II menjadi 92 (Sangat Baik). Hal serupa juga dialami olen peneliti sebulmnya Lestari (2016) dimana pada siklus ke 2 siswa yang mengalami peningkatan hasil belajar adalah 93,02\%. Dengan demikian, dapat disimpulkan bahwa Model Portofolio menunjukkan peningkatan hasil belajar siswa pada pembelajararan tematik terpadu tema IV subtema III dengan menggunakan model pembelajaran portofolio kelas V SD N 01 Campago Ipuh

\section{SIMPULAN}

Berdasarkan hasil penelitian dan pembahasan peneliti dapat disimpulkan bahwa setelah diterapkan model portofolio dalam pembelajaran tematik terpadu dapat meningkatkan hasil belajar siswa.

\section{DAFTAR RUJUKAN}

Majid, A. (2014). Pembelajaran Tematik Terpadu. Bandung: PT Remaja Rosdakarya Rusman. (2015). Model-model pembelajaran. Jakarta : PT Raja Grafindo Persada Kunandar. (2008). Langkah Mudah Penelitian Tindakan Kelas Sebagai Pengembangan Profesi Guru. Jakarta : PT Raja Grafindo Persada

Dwi, A \& Ratna, P. (2015). Penerapan Model Pembelajaran Berbasis PortofolioUntuk Meningkatkan Aktivitas Dan Hasil Belajar Pkn Siswa Kelas V. E-Journal PGSD Universitas Pendidikan Ganesha Jurusan PGSD . 3(1).

Istarani. (2012) . 58 Model Pembelajaran Inovatif. Medan : Media Persada

Reinita. (2011). Pelatihan Pelaksanaan Model Pembelajaran berbasis Portofolio pada Pembelajaran PKn Kelas IV SD Terhadap Mahasiswa Universitas Terbuka (UT ) Semester III di Kecamatan Mungka Kabupaten 50 Kota. Jurnal Ilmiah Suluah Bendang XI(2). 2011.(http://pedagogi.ppj.unp.ac.id/index.php/pedagogi.article/view/241)

Reinita. (2017). The Improvement Apication Value Of Cultural Character Nation To Students In Civil Learning With Value Clarification Technique Model In Class IV B SD N 16 Tarok Dipo Bukittinggi. ICEST. 118

Reinita. (2017). Pelatihan Pendekatan Value Technique model matriks dalam pembelajaran PKN-IPS Bagi seluruh guru SD Kecamatan Talawi Sawah Lunto. Jurnal Pedagogi. $\mathrm{XVII}(2)$

Supriadi. (2014). Efektifitas Pemberian Sanksi Pada Siswa Yang Melanggar Peraturan. Jurnal Pendidikan. 4(8) 